\title{
Prognostic Indicators in an Aggressive Pituitary Crooke's Cell Adenoma
}

\author{
K. Kovacs, C.C. Diep, E. Horvath, M. Cusimano, H. Smyth, C. Coire \\ M. Lombardero, B.W. Scheithauer, R.V. Lloyd
}

\begin{abstract}
Objective: To investigate prognostic indicators in an aggressive Crooke's cell adenoma of the pituitary. Methods: The surgically removed tumor was studied by histology, immunohistochemistry and transmission electron microscopy. Results: An aggressive invasive sellar tumor removed by repeated surgeries from a 43-year-old woman with pituitary related Cushing's disease was classified as a Crooke's cell adenoma of the pituitary. The application of several cell proliferation markers confirmed the aggressive nature of the tumor. Conclusions: The investigation of the present case provides additional evidence that pituitary Crooke's cell adenomas may possess aggressive behavior.
\end{abstract}

RÉSUMÉ: Indicateurs du pronostic d'un adénome pituitaire envahissant à cellules de Crooke: Objectif: Investiguer les indicateurs du pronostic de l'adénome pituitaire à cellules de Crooke. Méthodes: Le spécimen tumoral chirurgical a été étudié par histologie, immunohistochimie et microscopie électronique. Résultats: Une tumeur envahissante de la selle turcique a été enlevée chirurgicalement à plusieurs reprises chez une femme âgée de 43 ans ayant un Cushing d'origine pituitaire. Cette tumeur a été classifiée comme étant un adénome pituitaire à cellules de Crooke. L'étude au moyen de plusieurs marqueurs de prolifération cellulaire a confirmé la nature agressive de la tumeur. Conclusions: L'étude de ce cas démontre que les adénomes pituitaires à cellules de Crooke peuvent être envahissants.

Can. J. Neurol. Sci. 2005; 32: 540-545

Crooke's cell adenomas are an intriguing subtype of corticotroph adenomas of the pituitary. In contrast to those usually associated with Cushing's disease, the Crooke's cell variant contains large quantities of keratin immunopositive cytoplasmic intermediate filaments or microfilaments. The latter are well characterized by histology, immunohistochemistry and transmission electron microscopy. ${ }^{1-8}$ In 2003, George et $\mathrm{al}^{9}$ reported 36 cases of Crooke's cell adenomas and concluded that these tumors are innately aggressive and represent a distinct clinicopathologic entity. In the present article, we describe yet another case and concentrate upon the tumor's expression of cell proliferation markers. The patient was a 43-year-old woman showing clinical and laboratory evidence of pituitary related Cushing's disease. Three surgeries were carried out. Representative areas of the tumor were thoroughly studied by histology, immunohistochemistry and transmission electron microscopy to obtain a deeper insight into the biologic behavior of these tumors.

\section{Case Report}

Clinical and Laboratory Findings:

The patient, a 43-year-old woman, complained of visual blurring in the left eye, headache, fatigue, a reduction in energy, irritability, steady weight gain, one to two episodes of galactorrhea and secondary amenorrhea. She presented with truncal obesity, fullness and rubor of the face, a mild buffalo hump, and left lid ptosis in addition to folliculitis of the skin. The clinical impression was that of Cushing's disease. Ophthalmologic examination showed bitemporal hemianopsia. A computed tomogram (CT) scan and subsequently an magnetic resonance imaging (MRI) study demonstrated a large sellar mass with suprasellar extension (Figure 1). The tumor filled the left cavernous sinus and encased as well as constricted the left carotid artery. A diagnosis of invasive pituitary macroadenoma was made. Laboratory investigation revealed elevated blood adrenocorticotropin (ACTH) (20-114 pmol/L; normal range: 0-18 pmol/L), elevated blood cortisol levels (674$1303 \mathrm{nmol} / \mathrm{L}$; normal range: $83-690 \mathrm{nmol} / \mathrm{L}$ ), with loss of its diurnal rhythm,

From the Department of Laboratory Medicine and Pathobiology (KK, CCD, EH), Department of Neurosurgery (MC, HS), St. Michaels Hospital, University of Toronto, Toronto, ON, Canada; Department of Pathology (CC), Trillium Health Centre, Mississauga, ON, Canada; Department of Anatomy (ML), University of Santiago de Compostela, Lugo, Spain, Department of Pathology (BWS, RVL), Mayo Clinic, Rochester, MN, USA

Received February 23, 2005. ACCEPTED In FinAl FORM June 26, 2005. Reprint requests to: $\quad$ B.W. Scheithauer, Mayo Clinic, 200 First Street, SW, Rochester, MN 55905 USA 
a significantly increased urinary free cortisol concentration (169-14,212 $\mathrm{nmol} / \mathrm{d}$; normal range: $50-220 \mathrm{nmol} / \mathrm{d}$ ), and serum PRL (10-56 mcg/L; normal range: $0-25 \mathrm{mcg} / \mathrm{L})$. The thyroid function was well preserved. Emergency surgery (June 2004) precluded more tests being performed at that time. A large portion of the tumor was removed by the transsphenoidal approach. Postoperatively, the clinical features of Cushing's disease lessened and transient diabetes insipidus resolved. Due to tumor persistence and rapid regrowth, a second transsphenoidal surgery was carried out (June 2004). Left orbitofrontotemporal craniotomy (third surgery) for recurrence was also required (July 2004). Nonetheless, complete removal of the tumor could not be achieved.

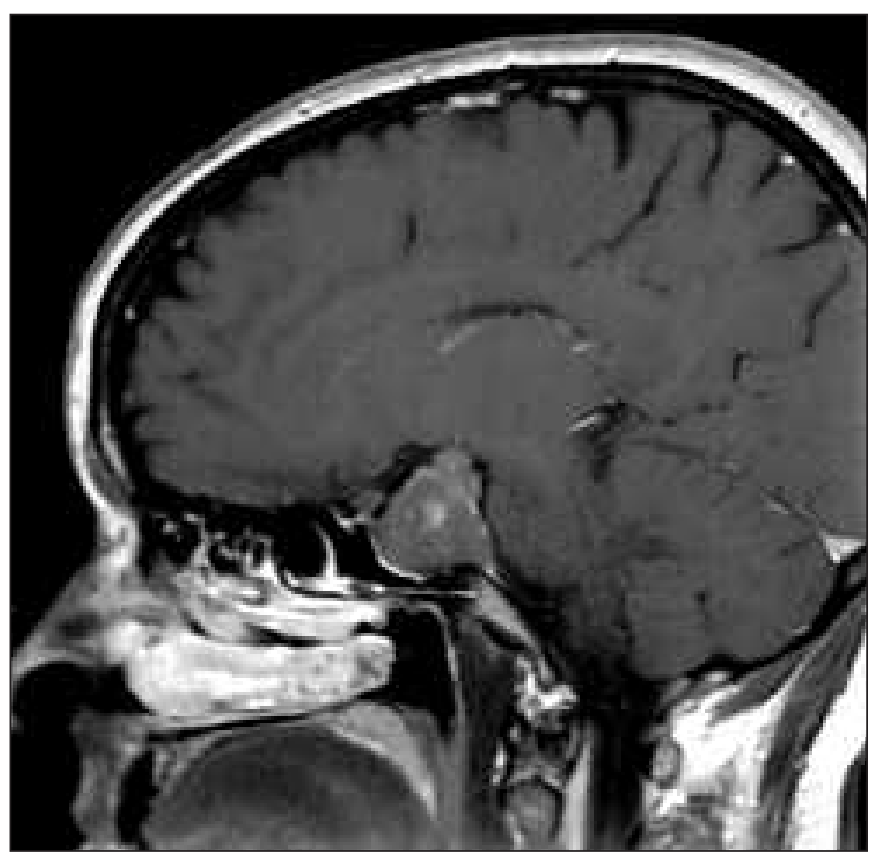

Figure 1: Sagittal magnetic Resonance Imaging of the invasive macroadenoma (post-gadolinium T1).

\section{Morphologic Methods:}

Specimens from three surgeries were fixed in $10 \%$ buffered formalin, dehydrated and embedded in paraffin. Sections of 4-6 $\mu \mathrm{m}$ thickness were stained with hematoxylin-eosin and the periodic acid-Schiff (PAS) technique. Immunostaining was performed using the streptavidin-biotin-peroxidase complex method. The full spectrum of pituitary hormone antibodies was applied. Details of the process, including antibodies employed, their sources and dilutions as well as the immunohistochemical procedure were described in previous papers. ${ }^{10,11}$ For quantification of Ki-67 labeling index, using the MIB-1 antibody, and of the other cell proliferation markers, 1000 adenoma cells were counted manually (tissue from third surgery). Microvessel density was evaluated on CD34 immunostained slides using an automated image analyzer as reported earlier. ${ }^{12-14}$ For transmission electron microscopy small fragments of tumor tissues were fixed in $2.5 \%$ glutaraldehyde, osmicated, dehydrated in graded ethanol, processed through propylene oxide, and embedded in epoxy-resin.

\section{Light Microscopic and Immunohistochemical Findings:}

Since no major morphologic differences were noted amongst the tissues removed from the three surgeries, the results are conjointly described. By light microscopy the tumor consisted of an amphophilic pituitary adenoma exhibiting a diffuse growth pattern. The tumor cells were PAS-positive and showed no significant cellular or nuclear pleomorphism. As in several cases of invasive pituitary adenomas ${ }^{15}$ mitotic figures were only rarely encountered (mitotic index 1-2\%; in non-aggressive adenomas: $0-1 \%$ ). A widespread and characteristic finding was that of Crooke's hyaline change (Figure 2). Similar to non-neoplastic Crooke's cells it was localized primarily in the perinuclear area but, in many adenoma cells, occupied nearly the entire cytoplasm. The glassy hyaline material was PAS-negative. In many cells the secretory granules were visible only in the perinuclear Golgi zone and in a narrow subplasmalemmal rim. No necrosis, inflammatory infiltrates or calcification were seen. In a few areas, mild interstitial fibrosis was noted. Immunostainings for adenohypophysial hormones showed

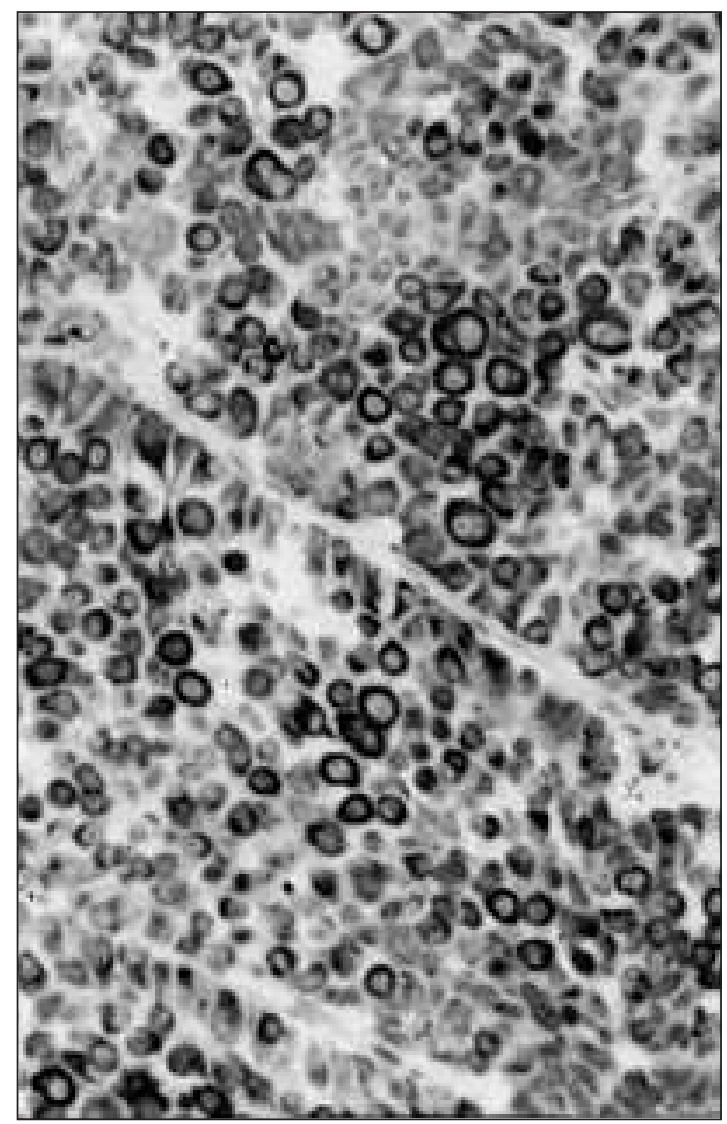

Figure 2: The Crooke's hyaline material is conclusively immunoreactive in the cytoplasm of adenoma cells for keratin-20. Immunostaining for keratin-20; original magnification $\times 400$. 


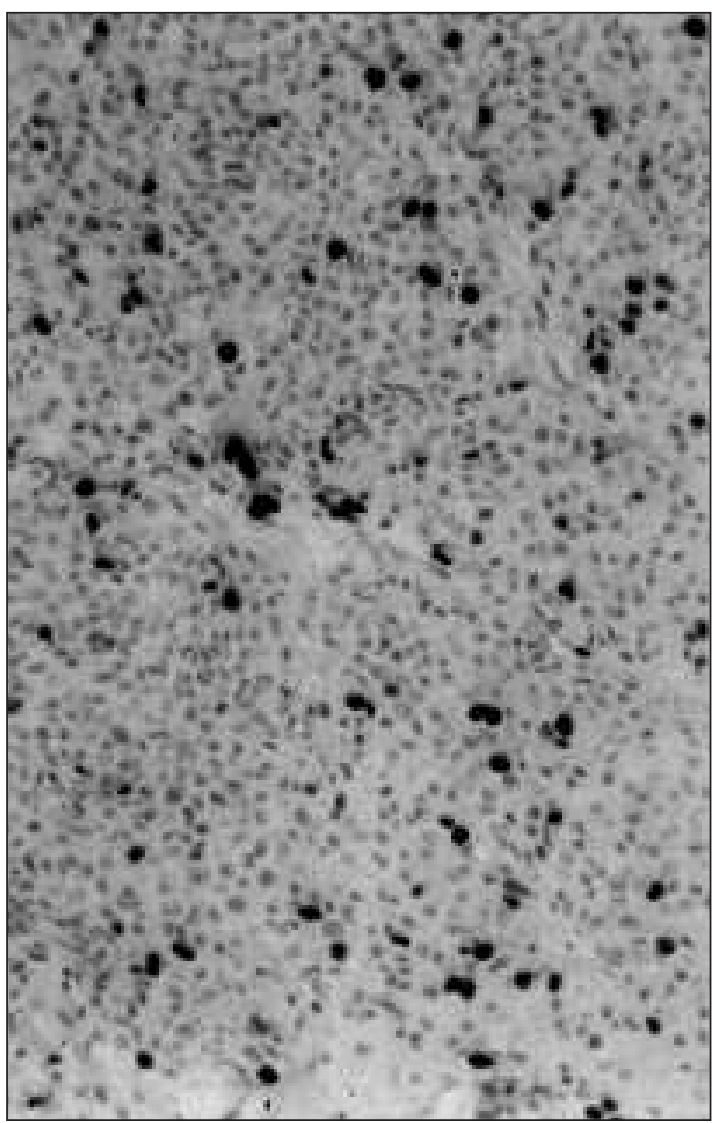

Figure 3: Immunostaining for the Ki-67 antigen shows several immunoreactive nuclei. Immunostaining for Ki-67 antigen using the MIB-1 antibody. Original magnification x 250.

conclusive cytoplasmic positivity for ACTH and beta endorphin. No reactivity was seen for growth hormone $(\mathrm{GH})$, prolactin (PRL), thyroid stimulating hormone (TSH), follicle stimulating hormone (FSH), lutienizing hormone (LH) or alpha subunit.

The Crooke's hyaline material was immunonegative for all adenohypophysial hormones, including ACTH and beta endorphin. Conclusive immunopositivity was apparent only for low molecular weight keratin, pankeratin and cytokeratin 20 (Figure 2). Staining for cytokeratin-7 was weak and focal. No staining was noted in the tumor cells for high molecular weight keratin, neurofilament protein, S-100 protein, glial fibrillary acidic protein, endothelial markers, (Factor-8, CD-31, CD-34), and myoid markers (actin, alpha-smooth muscle actin, smooth muscle myosin).

Immunopositivity was noted for a number of antigens, regarded as prognostic indicators. Labeling indices were as follows: Ki-67 antigen using the MIB-1 antibody: 6-10\% (in non-aggressive tumors: <3\%) (Figure 3), P-53: 1-2\% (in nonaggressive tumors: $0 \%$ ), P-27: $35-40 \%$ (in non-aggressive tumors: 40-80\%), topoisomerase 2 alpha: 15-20\% (in nonaggressive tumors: 0-12\%) (Figure 4). Vascular endothelial growth factor (VEGF): $85-90 \%$ ( in non-aggressive tumors: not quantified) (Fig 5), galectin-3: 20-25\% (in non-aggressive tumors: not quantified), and glucocorticoid receptor: $5-15 \%$ (in

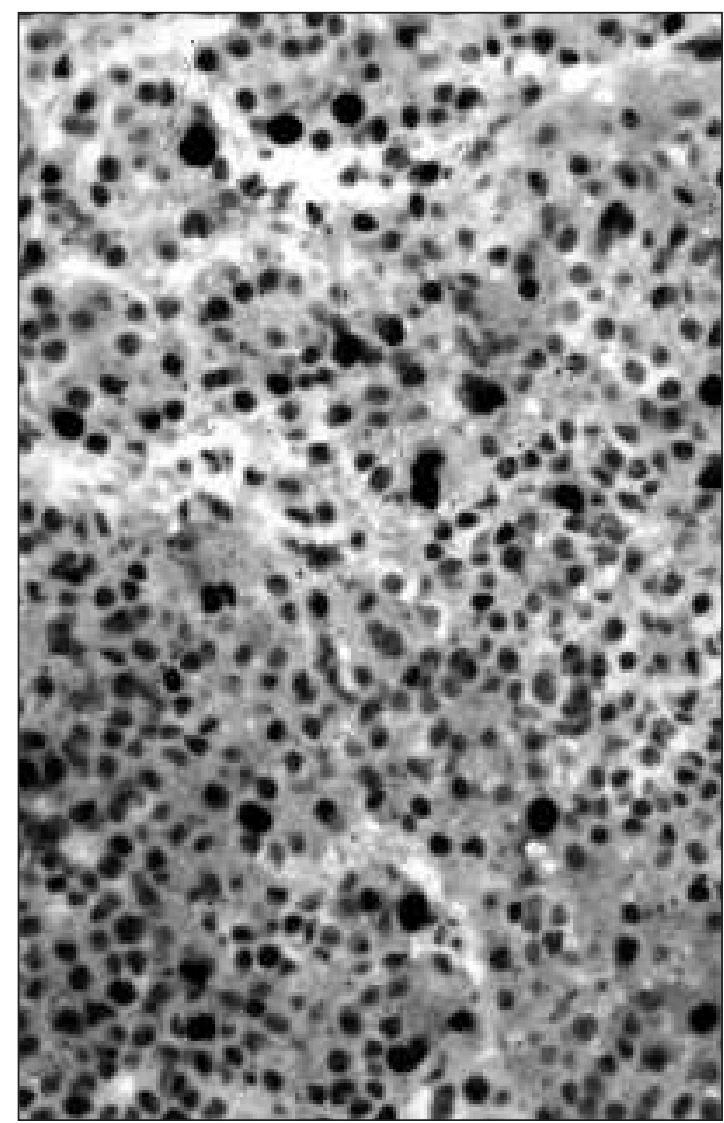

Figure 4: Immunostaining for topoisomerase 2 alpha demonstrates nuclear immunopositivity in several scattered adenoma cells. Immunostaining for topoisomerase 2 alpha. Original magnification $x$ 400 .

non-aggressive tumors: 3-85\%). Immunostaining was inconclusive for $\mathrm{COX}-2$, an additional cell proliferation marker. ${ }^{16}$ As in rapidly growing pituitary tumors, in contrast to slowly proliferating adenomas, ${ }^{12-14}$ many intratumoral blood vessels were identified. The microvessel density was $1.6-1.7 \%$ (in non-aggressive tumors: $0.5-2 \%$ ).

\section{Ultrastructural Findings}

On electron microscopy, the tumor consisted entirely of corticotrophs. The nuclei were irregular and contained prominent nucleoli in association with variable quantities of heterochromatin. The mitochondria were swollen but showed no major abnormalities. The most conspicuous finding was the massive cytoplasmic accumulation of bundles of 5-7 $\mu \mathrm{m}$ width perinuclear intermediate filaments. In many cells, they occupied almost the entire cytoplasmic area. Due to the sheer abundance of the filaments, the rough surfaced endoplasmic reticulum and Golgi zones were often obscured. Secretory granules varied in number and measured 200-250 $\mathrm{nm}$ in diameter. In many adenoma cells, they occupied only the paranuclear Golgi zone and the subplasmalemmal region. The ultrastructural findings are shown in Figures 6-7. 


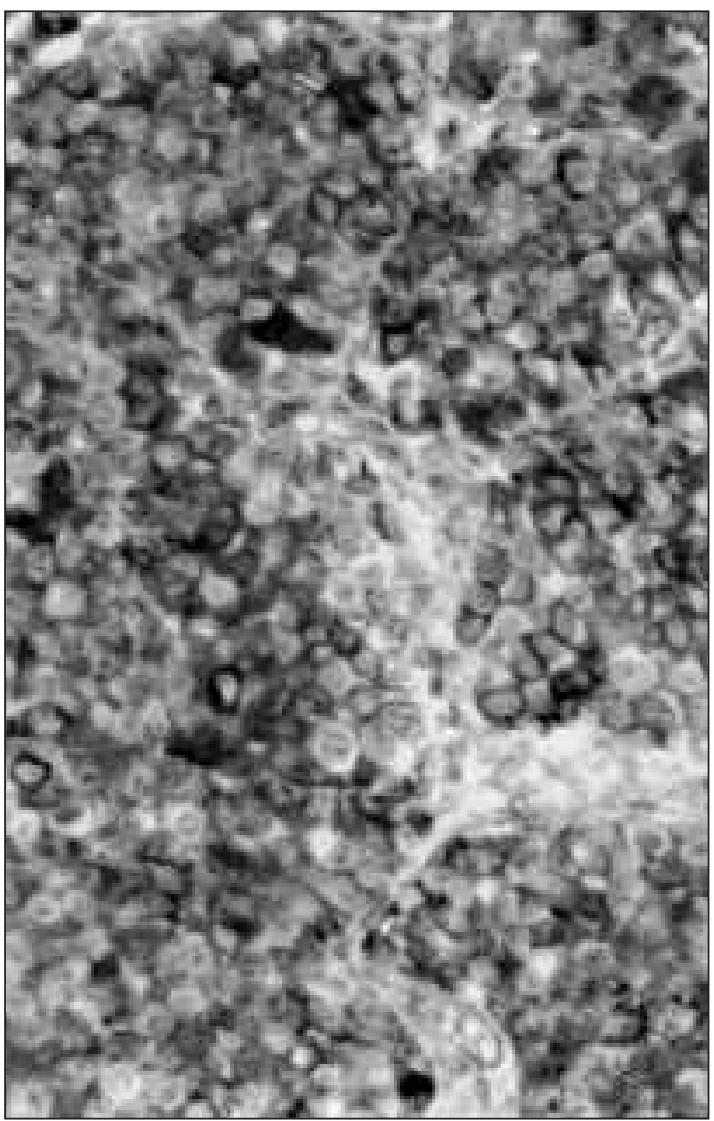

Figure 5: Immunostaining for VEGF shows conclusive cytoplasmic immunopositivity in many adenoma cells. Immunostaining for VEGF. Original magnification $x 400$.

\section{Discussion}

The existence of Crooke's hyaline change was first reported by Crooke, ${ }^{17}$ in 1935. Subsequently, several articles were published describing its histologic, immunohistochemical and ultrastructural features. ${ }^{1-8}$ It soon became apparent that Crooke's hyalinization occurs in pituitary corticotrophs exposed to endogenous or iatrogenic glucocorticoid excess. It was demonstrated in the corticotrophs of the non-tumorous portion of the adenohypophysis of patients with Cushing's disease harboring corticotroph adenoma accompanied by hypercorticism, ectopic ACTH syndrome, glucocorticoid hormone secreting adrenocortical adenomas and in subjects treated with pharmacologic doses of glucocorticoids. It was long believed that Crooke's hyalinization occurred only in nontumorous corticotrophs. Several publications, however, have documented Crooke's hyaline change in corticotroph adenomas. ${ }^{4,5,9,18,19}$ The view that tumors with abundance of keratin positive intermediate filaments should be classified as Crooke's cell adenomas was proposed recently by George et al..$^{9}$ In our experience, Crooke's cell adenomas are rare. Their exact frequency, however, has not been firmly established.

Since nontumorous Crooke's cells represent suppressed corticotrophs, it came as a surprise that Crooke's cell adenomas

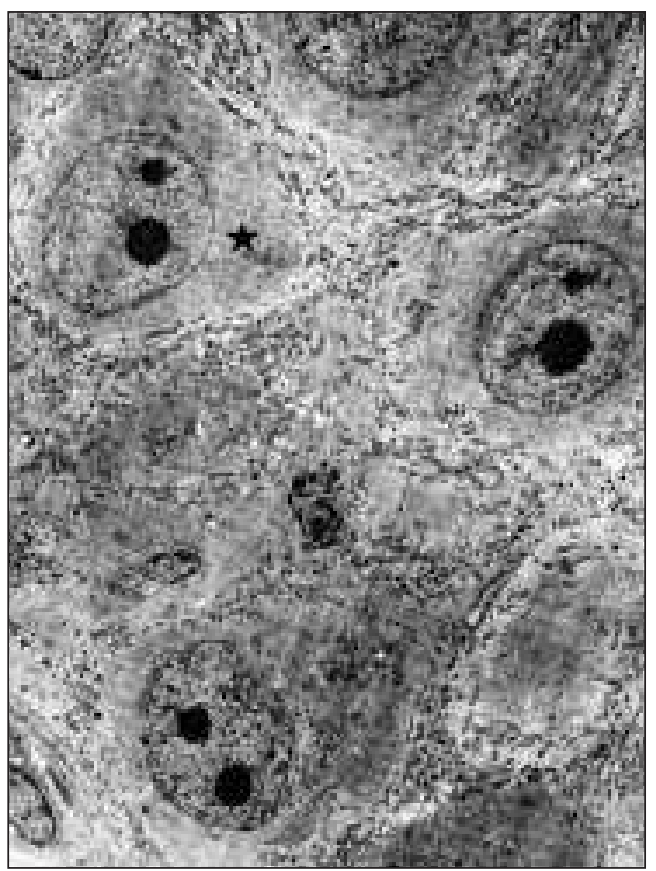

Figure 6: Electron micrograph of the Crooke's cell adenoma documents excessive accumulation of Crooke's hyaline substance involving the entire cytoplasmic area. The masses of cytokeratin filament (\$) partially obscure the small vesicular RER profiles and trap groups of mitochondria. $\times 5,000$.

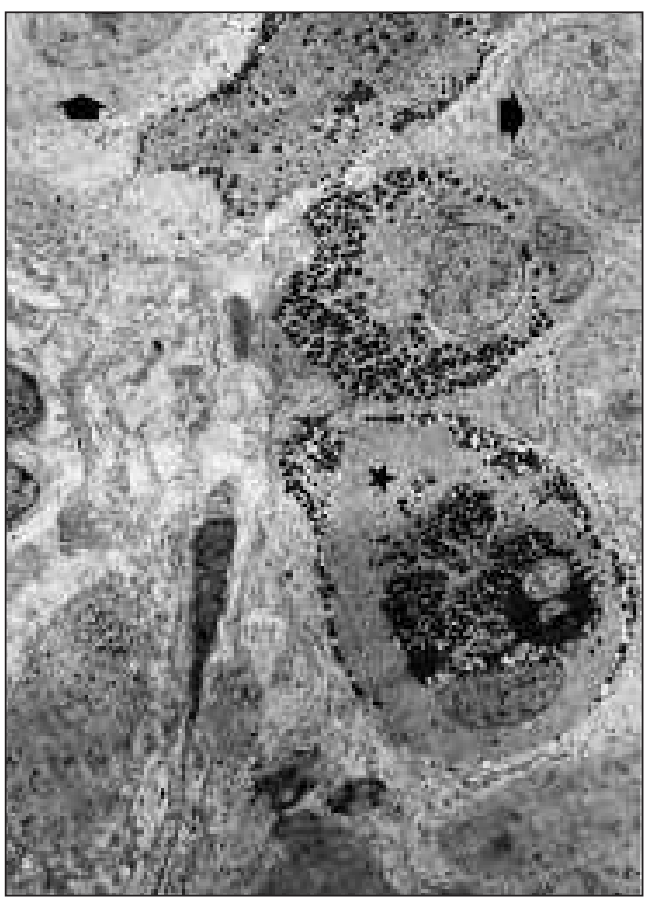

Figure 7: The aggressive tumor invades the adjacent non-tumorous gland. In the upper half of the figure neoplastic Crooke's cells are depicted (arrows). The lower half, showing an apparently intact acinus, contains a non-neoplastic Crooke's cell displaying abundant keratin filaments () and much larger and more numerous secretory granules, either displaced to the cell periphery or trapped within the Golgi region. $x 3,500$. 
are aggressive tumors. In the series of George et al, ${ }^{9}$ many tumors were found to be macroadenomas $(81 \%)$ invasive of their surrounds $(72 \%)$, prone to recurrence $(60 \%)$ and multiple recurrences (24\%). Even two cases of Crooke's cell carcinoma were encountered in the series of George et al. ${ }^{9}$ In summary, the behavior of our patient's tumor, an aggressive Crooke's cell adenoma that required multiple surgeries, is entirely in keeping with what is known about this unusual tumor.

The value of immunohistochemical markers of aggressiveness, was confirmed. Obviously, given financial constraints, not all these markers of growth potential, cell proliferation rate, and aggressiveness can be applied in every case. Preferences vary, but in our experience, the Ki-67 labeling of proliferating cells which entered the cell cycle has proven most useful. ${ }^{20}$

Not unexpectedly, increased Ki-67 labeling and p53 expression was observed in our case. Both have long been associated with large tumor size and invasiveness. ${ }^{20-22}$ Our indepth study of this single case also involved the application of several other markers recently found to be predictive of tumor aggressiveness and, in some instances, an unfavorable prognosis. These include: P-27, ${ }^{23,24}$ topoisomerase II alpha; ${ }^{25}$ galectin $3^{26}$ vascular endothelial growth factor $(\mathrm{VEGF})^{27-29}$ and extent of vascularization. ${ }^{12-14,30}$

Immunoreactivity for glucocorticoid receptor was reported in corticotroph adenomas, ${ }^{31}$ and other pituitary adenoma types. ${ }^{31}$ Also Expression of glucocorticoid receptor mRNA was demonstrated in pituitary corticotroph carcinomas. ${ }^{32}$ Several cells $(5-15 \%)$ of the Crooke's cell adenoma presented in this article were also immunoreactive for glucocorticoid receptor, suggesting that this receptor may play a crucial role in triggering the production of the Crooke's hyaline material. More studies are, however, required to establish the importance of the role of glucocorticoid receptor in Crooke's cell adenoma. It is not known whether the receptor is involved in the causation of aggressiveness and/or in the control of secretory activity of the tumor cells.

\section{ACKNOWLEDGEMENTS}

The authors thank Mr. and Mrs. Jarislowsky and the Lloyd Carr-Harris Foundation for their financial support; Mrs. Maureen Molson and Mrs. Denise Chase for their secretarial work; Ms. Vidya Beharry and Mr. Fabio Rotondo for their participation in the morphologic study and Mrs. Trina Foster for the literature search.

\section{REFERENCES}

1. Wagermark J, Wersall J. Ultrastructural features of Crooke's changes in pituitary basophil cells. Acta Pathol Microbiol Scand 1968; 72: 367-375

2. Halmi NS, McCormick WF, Decker DA Jr. The natural history of hyalinization of ACTH-MSH cells in man. Arch Path 1971; 91: 318-326.

3. DeCicco FA, Dekker A, Yunis EJ. Fine structure of the Crooke's hyaline change in the human pituitary gland. Arch Pathol 1972; 94: $65-70$

4. Felix IA, Horvath E, Kovacs K. Massive Crooke's hyalinization in corticotroph cell adeomas of the human pituitary. A histological, immunocytological, and electron microscopic study of three cases. Acta Neurochir 1981; 58: 235-243.

5. Horvath E, Kovacs K, Josse R. Pituitary corticotroph cell adenoma with marked abundance of microfilaments. Ultrastruct Pathol 1983; 5: 249-255.
6. Neumann PE, Horoupian DS, Goldman JE, Hess MA. Cytoplasmic filaments of Crooke's hyaline change belong to the cytokeratin class. An immunocytochemical and ultrastructural study. Am J Pathol 1984; 116: 214-222.

7. Kovacs K. The pathology of Cushing's disease. J Steroid Biochem Mol Biol 1993; 45: 179-182.

8. Kovacs K, Horvath E, Stefaneanu L, et al. Two cases of pituitary Crooke's cell adenoma without Cushing's disease: a histologic, immunocytochemical, electron microscopic and in situ hybridization study. Endocr Pathol 1999; 10: 65-72.

9. George DH, Scheithauer BW, Kovacs K, et al. Crooke's cell adenoma of the pituitary: an aggressive variant of corticotroph adenoma. Am J Surg Pathol 2003; 27: 1330-1336.

10. Kovacs K, Stefaneanu L, Horvath et al. Prolactin-producing pituitary tumor: resistance to dopamine agonist therapy. J Neurosurg 1995; 82: 886-890.

11. Kovacs K, Giannini C, Scheithauer BW, et al. Pituitary changes in Ataxia-telangiectasia syndrome: an immunocytochemical, in situ hybridization, and DNA cytometric study of three cases. Endocr Pathol 1997; 8: 195-203.

12. Jugenburg M, Kovacs K, Stefaneanu L, Scheithauer BW. Vasculature in non-tumorous hypophyses, pituitary adenomas, and carcinomas: a quantitative morphologic study. Endocr Pathol 1995; 6: 115-124.

13. Vidal S, Scheithauer BW, Kovacs K. Vascularity in nontumorous human pituitaries and incidental microadenomas: a morphometric study. Endocr Pathol. 2000; 11: 215-227.

14. Vidal S, Kovacs K, Horvath E, et al. Microvessel density in pituitary adenomas and carcinomas. Virchows Arch 2001; 438: 595-602.

15. Thapar K, Yamada Y, Scheithauer BW, et al. Assessment of mitotic activity in pituitary adenomas and carcinomas. Endocr Pathol 1996; 7: 215-221

16. Vidal S, Kovacs K, Bell D, et al. Cyclooxygenase-2 expression in human pituitary tumors. Cancer 2003; 97: 2814-2821.

17. Crooke AC. A change in the basophil cells of the pituitary gland common to conditions which exhibit the syndrome attributed to basophil adenoma. J Pathol Bacteriol 1935; 41: 339-349

18. Horvath E, Scheithauer BW, Kovacs K, Lloyd RV. Hypothalamus and pituitary. In: Graham DI, Lantos PL (Eds). Greenfield's Neuropathology Vol 1, (7th Ed), New York Arnold Publi, NY; 2002: 983-1062.

19. Ikeda H, Yoshimoto T, Ogawa Y, Mizoi K, Murakami O. Clinicopathological study of Cushing's disease with large pituitary adenoma. Clin Endocrinol 1997; 46:669-679.

20. Thapar K, Kovacs K, Scheithauer BW, et al. Proliferative activity and invasiveness among pituitary adenomas and carcinomas: an analysis using the MIB-1 antibody. Neurosurgery 1996; 38: 99106.

21. Kovacs K, Scheithauer BW, Horvath E, Lloyd RV. The World Health Organization classification of adenohypophysial neoplasms. A proposed five-tier scheme. Cancer 1996; 78: 502510 .

22. Thapar K, Scheithauer BW, Kovacs K, Pernicone PJ, Laws ER Jr. p53 expression in pituitary adenomas and carcinomas: correlation with invasiveness and tumor growth fractions. Neurosurgery 1996; 38: 765-770.

23. Jin L, Qian X, Kulig E, et al. Transforming growth factor-beta, transforming growth factor-beta receptor II, and p27Kip1 expression in nontumorous and neoplastic human pituitaries. Am J Pathol 1997; 151: 509-519.

24. Lidhar R, Korbonits M, Jordan S, et al. Low expression of the cell cycle inhibitor p27Kip1 in normal corticotroph cells, corticotroph tumors, and malignant pituitary tumors. J Clin Endocrinol Metab 1999; 84:3823- 3830.

25. Vidal S, Kovacs K, Horvath E et al. Topoisomerase II alpha expression in pituitary adenomas and carcinomas: relationship to tumor behavior. Mod Pathol 2002; 15: 1205-1212.

26. Riss D, Jin L, Qian X, et al. Differential expression of galectin-3 in pituitary tumors. Cancer Res 2003; 63: 2251-2255.

27. Lloyd RV, Scheithauer BW, Kuroki T, et al. Vascular endothelial growth factor (VEGF) expression in human pituitary adenomas and carcinomas. Endocr Pathol 1999; 10:229-235. 
28. Vidal S, Kovacs K, Cohen SM et al. Localization of vascular endothelial growth factor in nontumorous human pituitaries. Endocr Pathol 1999; 10: 109-122.

29. Yamamoto T, Nishizawa Y, Tsuji M, et al. Expression of vascular endothelial growth factor in normal pituitary cells and pituitary adenomas producing adrenocorticotropic hormone. Endocr Pathol 1999; 10:157-164.
30. de la Torre NG, Wass JA, Turner HE. Morphologic changes and molecular regulation of angiogenesis in pituitary adenomas. Front Horm Res 2004; 32: 133-145.

31. Kovacs K, Rotondo F, Stefaneanu L, et al. Glucocorticoid receptor expression in nontumorous human pituitaries and pituitary adenomas. Endocr Pathol 2000; 11: 267-276.

32. Gaffey TA, Scheithauer BW, Lloyd RV, et al. Corticotroph carcinoma of the pituitary: a clinicopathological study. Report of four cases. J Neurosurg 2002; 96: 352-360. 